\title{
Numerically-linguistic Anomalies of Gematria
}

\author{
Nekrasov S.A. \\ South Russian state technical university \\ *Corresponding Author: sergey_novoch@mail.ru
}

Copyright (C) 2013 Horizon Research Publishing All rights reserved.

\begin{abstract}
The article considers the numerically-linguistic anomaly for the theme of Christianity that is investigated by the probability theory methods. It is shown that the probability of casual occurrence of considered anomalies is rather small.
\end{abstract}

Keywords Law, Numerically-Linguistic Anomaly,

Probability,

\section{The Anomaly of the Roman Emperor Nero}

Nero, one of the most ill-famous Roman emperors, is the central figure of grandiose chronological and linguistic anomalies [1-4]. The full name of the emperor is Nero Claudius Caesar Augustus Germanicus [1,2]. Nero began the first persecution of Christians. In the Roman annals the following is written down about the executions of Christians: «Their killing was accompanied by tortures as they were dressed in skins of wild animals to be torn to pieces to death by dogs, crucified on crosses or doomed to death they were set on fire with the approach of darkness for the night illumination». Annals XV.44 (See Fig. 1,2).

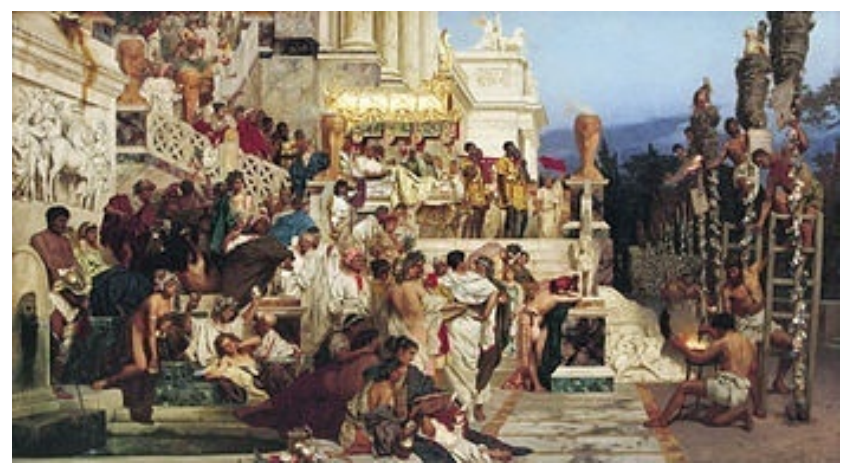

G. Semiradsky's painting, 1882 .

Figure 1. «The Torches of Christianity (Nero's Torches)».

It is considered to be scientifically proved $[1,2]$ that the famous Bible prophecy on the universal disaster "Apocalypse" is to a great extent devoted to the personality of the Emperor Nero. In the big Soviet Encyclopedia it is written that «in the Apocalypse of John as it is proved by the historical research the image of Antichrist contains a hint of the Roman emperor Nero».

In the Big Soviet Encyclopedia [1] it is written about the prophecy that «the Book of Revelation ... one of the books of New Testament, the most ancient of the Christian literary works which has come down to us ... was written in the middle of 68 - the beginning of $69 \mathrm{AD}$ (soon after the death of the Roman emperor Nero). In the Apocalypse ... the future destinies of the world and mankind: the forthcoming struggle between the «host of heaven» and the Antichrist, «a doomsday» are described. Due to this work the concept of the «number of the Beast» (number $\mathbf{6 6 6}$ is mentioned at the end of Chapter $\mathbf{1 3}$ of this book) came into the public consciousness.

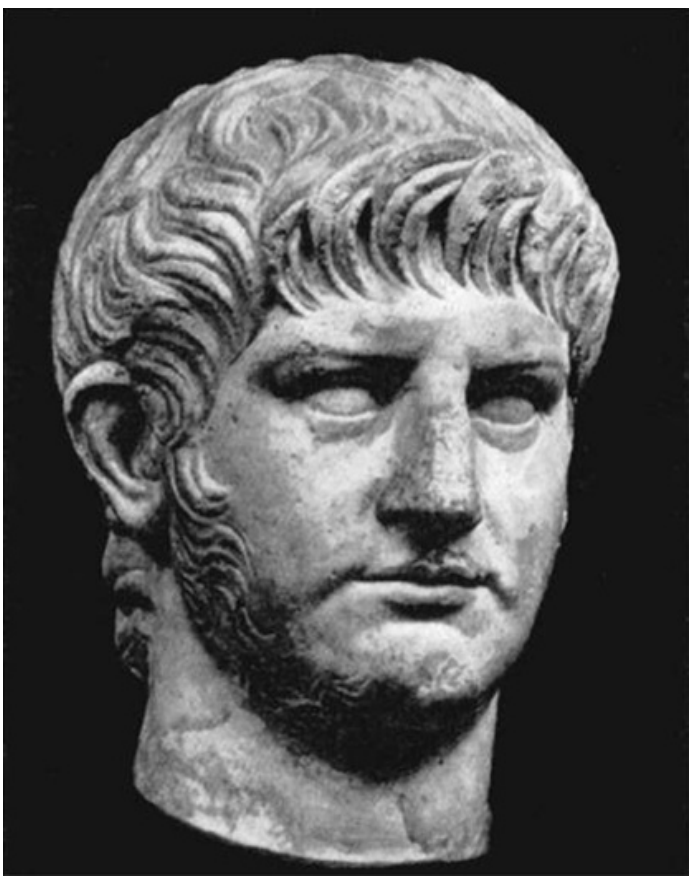

Figure 2. The Bust of Nero

As early as the antiquity the mystical property of the name «Nero» was revealed. During his rule in the east of the empire the coins were minted with the inscription in Hebrew «רסקורנור which is meant the "emperor Nero" («Neron Kesar»)). If we consider the digital values of the letters, their 
sum will be equal to the number of the Beast $\mathbf{6 6 6}$ (see Fig. 3). This coincidence, though being the only one, was repeatedly discussed in the corresponding literature and served as an additional basis for the mystification of the personality of Nero as the Antichrist.

The rule of the numbering of the Gematria alphabet letters is as follows: from the 1 st to the 10th - in a natural order, the 11 th letter receives number 20 , the 12 th - number $30, \ldots$ the 19 th - number 100 , the 20 th - number 200 etc., for example, the 30th letter receives number 3000 .

The code (the numerical content) of the word is equal to the sum of the numbers of its letters. The so-called gematria is based on this method of numbering.

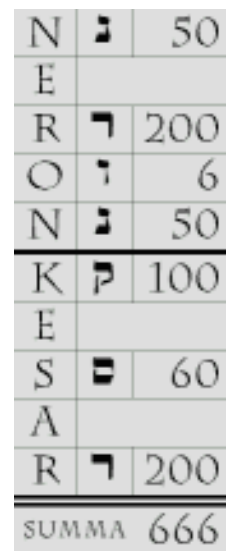

Figure 3. The numerical word meaning «Neron Kesar» is equal to Beast number 666

The number of the Beast $\mathbf{6 6 6}$ is the Apocalyptic number. The basic Romance language is French, one of the world languages. The French language goes back to the language of the ancient Rome. The numerical content of the word Antichrist is precisely equal to the number of the Beast in French:

$$
\mathrm{S}(\text { Antechrist })=666 .
$$

Calculation: $\mathrm{S}($ Antechrist $)=1+50+200+5+3+8+90$ $+9+100+200=666$.

If we write the Russian word "Антихрист" according to its sounds using the Latin letters, the word "Antihrist" will turn out:

$$
\mathrm{S}(\text { Antihrist })=1+666 .
$$

In the same way the name of the enemy of Christians is written in another Romance language, namely in Romanian.

The devilish character of the emperor Nero is reflected visually by the following phenomenal coincidences:

$$
\mathrm{S}(\text { Nero is Satan })=666 \text {. }
$$

Calculation: $\mathrm{S}($ Nero is Satan $)=50+5+90+60+9+100$ $+100+1+200+1+50=\mathbf{6 6 6}$.

For the subsequent coincidences with a view of brevity the calculation is not resulted (it simply to execute manually).

$$
\mathrm{S}(\text { Emperor Nero a Devil })=\mathbf{1 3} \cdot \mathbf{1 3} \bullet 6 \text {. }
$$

In Chapter $\mathbf{1 3}$ of the New Testament «The Revelation of the St. John the Divine» it is spoken about the coming of the Antichrist. It is scientifically proved that in the Apocalypse of John the image of the Antichrist corresponds to the Roman emperor Nero. The phenomenal numerically-linguistic coincidence (in English and in Russian) is a convincing evidence of it:

\section{S(Император Нерон есть пришествие Антихриста) $=6666$.}

In English: (Emperor Nero personifies the coming of the

\section{Antichrist).}

John's prophecy has a widely known name the "Apocalypse":

S(Нерон Клавдий Цезарь Август Германик есть Апокалипсис $)=\underline{\mathbf{1 3} \cdot 13 \cdot 13} \cdot(1+3)$.

In English: (Nero Claudius Caesar Augustus Germanikus

corresponds to the Apocalypse).

In the final sentence of Chapter $\mathbf{1 3}$ of Revelation it is said: «Who has the mind, consider the Beast number, for this number is human; it is number six hundred sixty six»:

S(Нерон Клавдий Цезарь Август Германик число $3 в е р я)=666 \cdot(6+6+6)$.

In English: (Nero Claudius Caesar Augustus Germanikus corresponds to number of the Beast).

John writes: «And has been overthrown a great dragon, ancient Snake, named as devil and Satan, seducing all Universe, has been overthrown on the earth, and his angels has been overthrown with him»:

\section{S(Nero Claudius Caesar Augustus Germanicus is Dragon}

$$
\text { tempter })=666 \cdot 6 .
$$

Nero was suspicious and cruel. According to Suetonius Trankvill "he already executed everybody and for everything without distinction".

S(Нерон Клавдий Цезарь Август Германик есть маньяк) $=13 \cdot 13 \cdot 103$.

In English: (Nero Claudius Caesar Augustus Germanikus is

a maniac).

\section{Calculation of the probabilities coincidence}

On the basis of the existing methods of the probability theory the following estimations of the probabilities of coincidence under the condition of their casual character are strictly proved $[3,4]$ :

The numerical content of a word-combination is precisely multiple to number 666 in one case out of 666 . The same rule is true and for numbers $13 \cdot 13=169,13 \cdot 13 \cdot 13=2197$. The exact divisibility for number 6666 can be fulfilled casually only in one case out of 6666 cases. For the rough coincidence with the error of not more than 1 the probability is more three times.

For the perfect coincidence the probability is much less. For example, the numerical content of a word-combination is precisely equal to number 666 in one case out of 10000 . To find out only one similar exact coincidence for the sum equal to 6666 , one would have to run back over 100000 phrases at 
a guess.

The number of combinations of words depends on the volume of the thesaurus of a theme $-N$ words, then, for example, the combinations from two words $N^{2}$.

Actually a matrix of words is the rarefied: only limited number of words $k \quad(k<<N)$ enters in semantic communication with one considered word.

Thus, the probability of similar coincidence is negligibly small. Hence, it is possible to draw a conclusion on their nonrandomness which the data below prove that.

In the New Testament the following is told. Number 666 is not only the Beast number, but also number human. According to noted circumstance we will consider linguistic anomaly on a positive theme.

\section{Anomaly of Jesus Christ}

Jesus Christ is the greatest personality in history who is proclaimed God-Man by Christians. The «Christ» from Greek means the «Messiah and the Lord's Annointed» . Gematria confirms the sanctity of Jesus:

$\mathrm{S}($ God Angelic Soul $)=666$.

$\mathrm{S}($ Divine Son is Soul of Believers $)=666 \bullet 1 \bullet 3$. $\mathrm{S}($ Son Human Belief $)=666$.

$\mathrm{S}($ God Son Catholic God $)=666$.

$\mathrm{S}($ God Son Soul of World $)=13 \cdot 13 \cdot 1 \cdot 3 \cdot 1 \cdot 3$.

$\mathrm{S}($ The God Spirit the Believer $)=\mathbf{1 3} \cdot \mathbf{1 3} \cdot 1 \cdot 3 \cdot 1 \cdot 3$. $\mathrm{S}($ God Son Belief $)=\mathbf{1 3} \cdot \mathbf{1 3} \cdot 2$.

$\mathrm{S}($ The Son Human is the Believer $)=\mathbf{1 3} \cdot 13 \cdot 10$.

$\mathrm{S}($ Christian Messiah Soul of Christians $)=\mathbf{1 3} \cdot \mathbf{1 3} \cdot 11$.

$\mathrm{S}($ The Christian God The Catholic God $)=\mathbf{1 3} \cdot \mathbf{1 3} \bullet$.

In Russian:

$\mathrm{S}($ Иисус Христос святой дух $)=\underline{\mathbf{1 3} \cdot 13 \cdot 13} \cdot(1+3)$.

In English: (Jesus Christ is the Holy Spirit)

$\mathrm{S}($ Помазанник Божий есть святой дух $)=\underline{\mathbf{1 3} \cdot \mathbf{1 3} \cdot \mathbf{1 3}} \cdot 5$. In English: (The anointed sovereign Divine is the Holy Spirit)

$\mathrm{S}($ Спаситель божество $)=666 \cdot 6$.

In English: (the Savior is a deity)

$\mathrm{S}($ Иисус Богочеловек $)=13 \cdot 13 \cdot 1 \cdot 3 \cdot 1 \cdot 3$.

In English: (Jesus is the divine person)

$\mathrm{S}($ Господь Бог душа мира $)=666 \bullet 7$.

In English: (the Lord the God is soul of the world)

$\mathrm{S}($ Господь Бог есть душа христиан $)=\underline{\mathbf{1 3} \cdot 13 \cdot 13} \cdot(1+3)$.

In English: (the Lord the God is soul of Christians)

Jesus was born in the well-known town of Bethlehem:

$\mathrm{S}($ The God of Christians is Bethlehem $)=\mathbf{6 6 6} \cdot 2$.

The saviour of people was born from Spirit Sacred at Maiden Maria (Maria is a name of the Virgin in Latin, German, Spanish and Portuguese languages).

Virgin Mary is a kind magician who is famous for the miracle of the Virgin Birth of Christ. According to a doctrine of the Roman church she like the Son of God was born as the result of the immaculate conception and died under many wonderful events (after Holy Assumption, i.e. Mary's discarnation, the wonderful reunion of her soul and body and their ascension to heaven follows. The Catholic church declared Mary the «Mother of Church»). The corresponding coincidences are the following:

$$
\begin{aligned}
\mathrm{S}(\text { The sacred Maiden Maria }) & =666 . \\
\mathrm{S}(\text { Madonna soul of Christians }) & =666 \cdot 2 .
\end{aligned}
$$

The Lady day, a Christian holiday, is devoted to announcement by archangel Gabriel to Virgin Mary the secret of impersonation of the God of the Word from her (the Gospel of Luke 1:26-38).

$\mathrm{S}($ Maiden Maria Lady day $)=\mathbf{1 3} \cdot \mathbf{1 3} \cdot 10$.

Maria differed mild customs, to her was attributed the sermon activity:

$\mathrm{S}($ Maiden Maria Angelic Soul $)=\mathbf{1 3} \cdot 13 \cdot 5$.

$\mathrm{S}($ Maiden Maria is Messianic $)=\mathbf{1 3} \cdot \mathbf{1 3} \cdot(1+3)$.

$\mathrm{S}($ Maria the Teacher $)=\mathbf{6 6 6}$.

Jesus spent most of his life in the city of Nazareth. He was a Jew by nationality. The corresponding linguistic coincidences are shown below:

$\mathrm{S}($ Christ is the Prophet of the Israeli People $)=\mathbf{6 6 6} \cdot 1 \cdot 3$. $\mathrm{S}(\mathrm{Jesus}$ is the Jew $)=\mathbf{1 3} \cdot \mathbf{1 3} \cdot 8$.

$\mathrm{S}($ Христианский Бог еврей $)=\mathbf{6 6 6} \cdot(-1+3)$.

In English: (the Christian God is the Jew)

The Jews consider themselves the God-selected people: $\mathrm{S}($ God is Patron of Jews $)=\mathbf{6 6 6} 2$.

$\mathrm{S}($ Son Human is Christian God of Jewish People $)=$ $\underline{13 \cdot 13 \cdot 13}$.

$\mathrm{S}($ God of Christians Patron of Jews $)=\mathbf{1 3} \cdot \mathbf{1 3} \cdot 11$. $\mathrm{S}($ Израильский народ Богом избранный $)=\mathbf{6 6 6} 1 \cdot 3 \cdot 1 \cdot 3$.

In English: (the Israeli people is the God the elite)

When Jesus came of age (the so-called Bar Mitsvah), during the family pilgrimage to Jerusalem the youth disappeared and was found in the Jerusalem temple «in the middle of the teachers, listening to them and asking them» that these rabbis «wonder His reason and answers» (the Gospel of Luka 2, 47):

\section{$\mathrm{S}($ God is Talent $)=666$.}

$\mathrm{S}($ Иисус Христос есть умный $)=666 \bullet 11$. In English: (Jesus Christ is clever)

The number of pupils of the Savior (Apostles) was equal 12: $\mathrm{S}($ Savior twelve Apostles) $=13 \cdot 13 \cdot(13+1)$.

$\mathrm{S}($ Помазанник Божий Апостолы $)=13 \cdot 13 \cdot(6+6+6)$.

In English: (The anointed sovereign divine and Apostles)

The injust court has sentenced Jesus to execution and he has been crucified on a cross:

$\mathrm{S}($ The Son Human is a Crucifixion on a cross $)=13 \cdot 13 \cdot 15$.

$\mathrm{S}($ Господь распятие на кресте $)=13 \cdot 13 \cdot 61$.

In English: (the Lord and the crucifixion on a cross)

$\mathrm{S}($ Иисус Христос из Назарета распятие на кресте) $=$ $13 \cdot 13 \cdot 53$.

In English: (Jesus Christ from Nazareth and the crucifixion on a cross)

The birth, life, death and Jesus Christ revival are surrounded by weight of secrets. Until recently the science challenged even a reality of a historical figure of Jesus:

$\mathrm{S}($ Christian God Sacred Legend $)=\mathbf{1 3} \cdot \mathbf{1 3} \cdot 5$. 
$\mathrm{S}($ Христианский мессия есть тайна $)=\underline{\mathbf{1 3 \cdot 1 3 \cdot 1 3}} \cdot 5$. In English: (the Christian Messiah is secret) Jesus has become famous as the great wizard, the miracle man:

$\mathrm{S}($ Jesus Christ is the Sorcerer $)=\mathbf{1 3} \cdot \mathbf{1 3} \cdot 10$.

$\mathrm{S}($ Иисус Христос есть великий маг) = 13•13•1•3•10.

In English: (Jesus Christ is the great magician) Corresponding coincidence:

$$
\mathrm{S}(\text { Catholic God is Mercy })=666 \cdot 2 \text {. }
$$

$\mathrm{S}(\operatorname{God}$ of Christians is Justice Sword $)=\underline{\mathbf{1 3} \cdot \mathbf{1 3} \cdot \mathbf{1 3}}$.

$\mathrm{S}($ Бог христиан праведник $)=\mathbf{6 6 6} \cdot(-1+3)$.

In English: (the God of Christians is the righteous person)

$\mathrm{S}($ Бог человечества есть ангел) $=\mathbf{6 6 6} 8$.

In English: (the God of mankind is an angel)

Christianity - the main world religion:

$\mathrm{S}($ The Cristian God Religion $)=\mathbf{1 3} \cdot \mathbf{1 3} \cdot(6+6-6)$.

$\mathrm{S}($ God from Nazareth World Religion $)=\mathbf{1 3} \cdot \mathbf{1 3} \cdot(\mathbf{1 3}+1)$.

$\mathrm{S}($ Иисус Христос вера $)=\mathbf{1 3 \cdot 1 3 \cdot 1 0 . ~}$

In English: (Jesus Christ and belief)

$\mathrm{S}($ Помазанник Божий есть вера $)=\mathbf{1 3 \cdot 1 3 \cdot 2 3}$.

In English: (the Anointed sovereign divine corresponds to the belief)

Jesus and Mary - tops, pillars of this religion: $\mathrm{S}($ Jesus Top $)=\mathbf{1 3} \cdot \mathbf{1 3} \cdot 5$.

$\mathrm{S}($ The Mother of God Tops $)=\mathbf{1 3 \cdot 1 3 \cdot 7}$.

$\mathrm{S}($ Madonna is a main religion $)=\mathbf{1 3} \cdot \mathbf{1 3} \cdot(1+3)$.

«Logos» from Greek means «speech, word, concept, measure». In the Christian doctrine Logos designates the reasonable principle ruling the world, and the God-son as the Intermediary between the God-father and the world:

$\mathrm{S}($ Christ Logos $)=1+666$.

The doctrine of Jesus is stated in the final part of the Scriptus - the New Testament:

$\mathrm{S}($ Christ from Nazareth the new testament $)=\mathbf{6 6 6} \cdot 5$.

$\mathrm{S}($ Иисус Священное Писание $)=\mathbf{6 6 6}(13-1)$.

In English: (Jesus and the Scriptus)

$\mathrm{S}($ Бог католиков Евангелие $)=\mathbf{6 6 6}$.

In English: (the God of Catholics and the Gospel)

$\mathrm{S}($ The Bible is a Divine sign $)=\mathbf{1 3} \cdot \mathbf{1 3} \cdot(6+6-6)$.

$\mathrm{S}($ The Bible is the Holy Spirit $)=\mathbf{1 3} \cdot \mathbf{1 3} \cdot 11$.

$\mathrm{S}($ The New Testament the Newcomer $)=\mathbf{1 3} \cdot \mathbf{1 3} \cdot 15$.

Jesus Christ - the greatest prophet:

$\mathrm{S}($ Jesus Prophecy $)=\mathbf{1 3} \cdot \mathbf{1 3} \cdot 1 \cdot 3 \cdot 1 \cdot 3$.

$\mathrm{S}($ The divine Son is the Great Prophet $)=\mathbf{1 3} \cdot \mathbf{1 3} \bullet(\mathbf{1 3}-1)$.

\section{Lenin and Stalin - two great Antichrists}

Vladimir Ilich Lenin (Ulyanov) and Joseph Vissarionovich Stalin (Dzhugashvili) - two greatest political criminals. They have made set of rather known villainies. One of the most known crimes - execution of a family of the emperor of Russia. Communists severely executed not only the tsar, the tsarina, but also juvenile children. Some system has created linguistic coincidence which reflect the given historical event $[3,4]$.

S(V I Ulyanov Lenin Execution of the Tsar $)=666 \cdot 6$.

$\mathrm{S}($ Ульянов казнь царской семьи $)=666 \cdot 25$.

In English: (Ulyanov corresponds to the execution of the imperial family).

$\mathrm{S}($ Joseph Vissarionovich Dzhugashvili is execution of the $T S A R)=\mathbf{1 3} \cdot \mathbf{1 3} \cdot 31$.

$\mathrm{S}($ И В Джугашвили казнь царя $)=\underline{\mathbf{1 3} \cdot \mathbf{1 3} \cdot \mathbf{1 3}} \cdot 5$.

In English: (I VDzhugashvili corresponds to the execution of the tsar).

They have become famous for reprisals against clergy. Lenin's known order on execution of 10000 priests had remarkable number 666 (see Fig. 4). Stalin has especially become famous for the reprisals. Corresponding coincidence:

$\mathrm{S}($ Stalin is reprisals against clergy $)=\underline{\mathbf{1 3} \cdot 13 \cdot 13}$.

Ulyanov-Lenin and Dzhugashvili-Stalin have been betrayed to an anathema and are proclaimed as Antichrists. Linguistic coincidence also testifies, that leaders of communists are the Antichrists:

$$
\begin{gathered}
\mathrm{S}(\boldsymbol{V} \text { I Lenin is } \text { Antichrist })=\mathbf{6 6 6}(-1+3) . \\
\mathrm{S}(\text { Lenin The Beast })=-1+666 . \\
\mathrm{S}(\text { Dzhugashvili The Beast })=\underline{\mathbf{1 3} \cdot 13 \cdot 13} .
\end{gathered}
$$

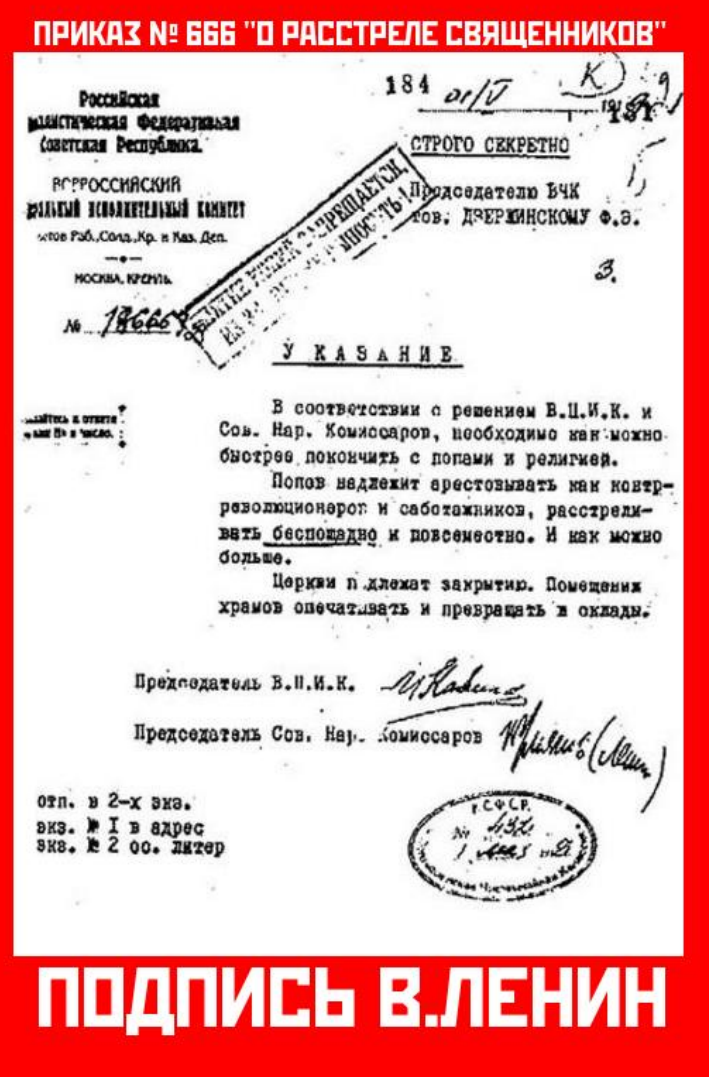

Figure 4. V.I.Lenin's order on executions of clerics

Antichrist is the servant of the Devil. Some system philosophically compares Ulyanov-Lenin and Dzhugashvili 
-Stalin with the Devil $[3,4]$. The devil is an evil ghost, a malicious angel. At it there are the several names. The most known names are Satan, Demon, Tchort, Beelzebub, Lucifer, Mephistopheles, the fallen angel.

Coincidences on this theme for Lenin and Stalin (see Fig. $5)$ :

$\mathrm{S}($ Ulyanov the Lucifer $)=\underline{13 \cdot 13 \cdot 13}$.

$\mathrm{S}($ Vladimir Ilich Ulyanov is the Demon $)=\mathbf{6 6 6}(1+3)$.

$\mathrm{S}($ Vladimir Ulyanov Lenin is the Fiend $)=\mathbf{6 6 6} \cdot(1+3)$. $\mathrm{S}($ Vladimir Lenin the Fiend $)=\mathbf{1 3} \cdot \mathbf{1 3} \cdot(6+6-6)$.

$\mathrm{S}($ Vladimir Ilich Ulyanov is the $\mathrm{Sin})=\mathbf{6 6 6} \cdot(1+3)$. $\mathrm{S}($ V I Ulyanov Lenin Damned $)=1+\underline{\mathbf{1 3} \cdot 13 \cdot 13}$. $\mathrm{S}($ Ulyanov Lenin is the Dragon the tempter $)=$

$$
13 \cdot 13 \cdot(6+6+6) \text {. }
$$

$\mathrm{S}($ В И Ленин есть Нечистый $)=\underline{13 \cdot 13 \cdot 13} 1 \bullet 3$. In English: (VI Lenin is Russian Evil spirit).

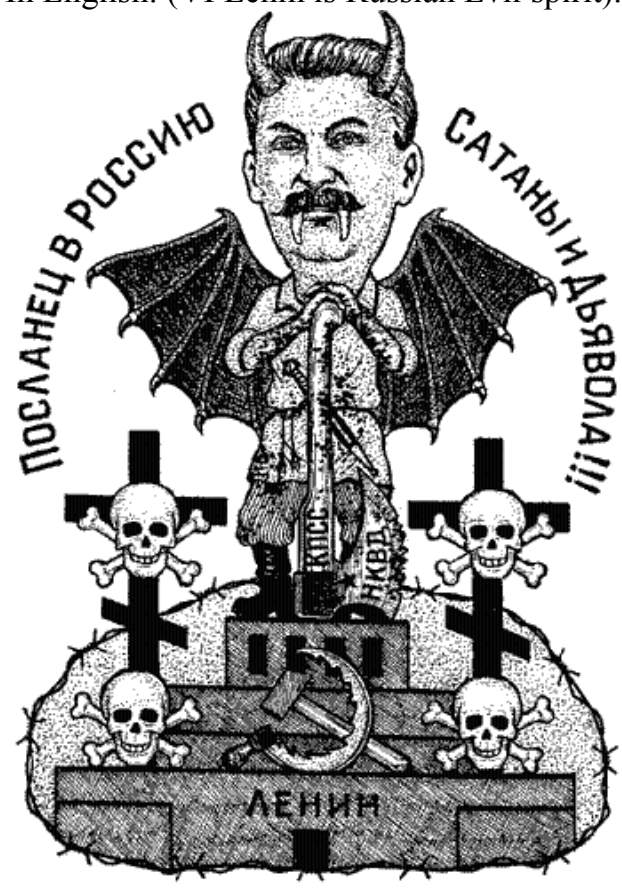

Figure5. A cartoon to Stalin (Inscription: the messenger of the Satan and the Devil)

$$
\begin{aligned}
\mathrm{S}(\boldsymbol{J} \text { Stalin is Danger }) & =666 . \\
\mathrm{S}(\text { Иосиф Cталин чёрm }) & =666 \cdot 1 \cdot 3 .
\end{aligned}
$$

In English: (Joseph Stalin is the Tchort (Russian Evil spirit)).

$\mathrm{S}($ Иосиф Виссарионович Джугашвили есть Сатана $)=1$ $+6666$.

In English: (Joseph Vissarionovich Dzhugashvili is the Satan).

The beginning of board of communists was marked by criminality revelry under the slogan «plunder stolen». Stalin-Dzhugashvili during the pre-revolutionary period was engaged in robbery much. Corresponding coincidence:

$\mathrm{S}(\mathrm{V}$ Ulyanov is Crime $)=\underline{\mathbf{1 3} \cdot \mathbf{1 3} \cdot \mathbf{1 3}}$.

$\mathrm{S}($ Joseph Vissarionovich Stalin is Crime $)=1+\underline{\mathbf{1 3} \cdot \mathbf{1 3} \cdot 13}$.

$\mathrm{S}(\mathrm{J} V$ Dzhugashvili is a criminal authority $)=\mathbf{6 6 6} 6$.

$\mathrm{S}(\mathrm{J}$ V Dzhugashvili the thief in the law $)=\mathbf{6 6 6} \cdot 5$.

$\mathrm{S}($ И В Сталин есть преступный $)=6666$.
In English: (I V Stalin is criminal).

V.I.Uljanov-Lenin has become history as the dictator, the Tyrant, the enemy of Russia, the new tsar Herod the Great. Corresponding coincidence:

$\mathrm{S}(\mathrm{V}$ Lenin the tyrant $)=\mathbf{6 6 6} \cdot 1 \cdot 3$.

$\mathrm{S}($ Vladimir Lenin is the executioner of Russia $)=$ $13 \cdot 13 \cdot(6+6+6)$.

$\mathrm{S}($ Иосиф Сталин авантюрист $)=6666$.

In English: (Joseph Stalin is the adventurer).

V.I.Uljanov-Lenin was the communist, a socialist, the Soviet politician, the Kremlin governor. Corresponding coincidence:

$\mathrm{S}($ Ulyanov Lenin Socialist $)=\underline{\mathbf{1 3} \cdot 13 \cdot 13}$.

$\mathrm{S}$ (В И Ленин социалистический) $=-1+\underline{\mathbf{1 3} \cdot 13 \cdot 13}$.

In English: (VI Lenin is socialist).

$\mathrm{S}($ Lenin is a political $)=666$.

$\mathrm{S}($ Vladimir Ulyanov Lenin Soviet $)=\mathbf{1 3} \cdot \mathbf{1 3} \cdot(6+6+6)$.

$\mathrm{S}($ Lenin is the Professional revolutionary $)=\mathbf{1 3} \cdot \mathbf{1 3} \cdot(6+6+6)$.

$\mathrm{S}($ Ulyanov the Kremlin $)=666 \cdot 1 \cdot 3$.

$\mathrm{S}($ Vladimir Ilich Lenin is the Kremlin $)=\mathbf{1 3} \cdot \mathbf{1 3} \bullet 8$.

Dzhugashvili-Stalin also was a socialist, the communist. $\mathrm{He}$ has been named the leader of world revolution and proletariat.

$\mathrm{S}(\boldsymbol{J}$ Dzhugashvili Socialist $)=1+\underline{\mathbf{1 3} \cdot 13 \cdot 13}$.

$\mathrm{S}($ Dzhugashvili is political $)=\underline{\mathbf{1 3} \cdot 13 \cdot 13}$.

$\mathrm{S}(\mathrm{J}$ V Stalin is the mausoleum $)=\mathbf{6 6 6} \cdot 1 \cdot 3$.

Stalin came from caucasus, from Georgia.

$\mathrm{S}(J$ V Dzhugashvili is a Caucasian $)=\mathbf{6 6 6} \cdot(1+3)$.

$\mathrm{S}($ И Сталин есть Грузия $)=\mathbf{1 3} \cdot \mathbf{1 3} \bullet 60$.

In English: (I Stalin is Georgia).

\section{Conclusion}

Keywords and word-combinations of the considered themes possess rather remarkable property of Quantization: the numerical contents of these words is multiple to remarkable numbers 666, 6666 and to number 13 degrees.

Rather small probability of the considered coincidences is the proof of the influence of divine forces on mankind, including on human languages.

\section{REFERENCES}

[1] The big Soviet encyclopaedia./Main Editor A.M.Prohorov. Moscow: the Soviet encyclopae-dia, 1977.

[2] Cyril's and Mephody's big encyclopaedia, 7 edition, 2003.

[3] Nekrasov S.A. Linguistic anomaly Christian theme./ Bulletin of development of science and education. 1 (2013), pp. 74-85.

[4] Nekrasov S.A. Chronological, information and biophysical anomalies of system ETA. Pub-lishing house Palmarium Academic Press (Germany). 2012. ISBN 978-3-8473-9440-2. (ljubl-juknigi.ru) 
[5] Baghdasaryan B.E. The Idea of the Antichrist in the Russian historiosophical thoughts. Ar-mageddon. 1999. № 1.
[6] Robert W. Faid. A Scientific Approach to More Biblical Mysteries. 1995. ISBN 0-89221-283-7. 